\title{
PENGARUH STANDAR NASIONAL PENDIDIKAN TERHADAP KESEMPATAN KERJA LULUSAN AKUNTANSI MELALUI KELUARAN SATUAN PENDIDIKAN SMK DI KOTA SURABAYA
}

\author{
Eka Hendi Andriansyah*
}

\begin{abstract}
This study aims to determine the effect of the graduates' job opportunities on the National Education Standard mediated by vocational schools in Surabaya. The study was conducted at 31 vocational schools in Surabaya, particulary the accounting department. The study concludes that the implementation of National Education Standard results in good education quality; however, the academic achievement is not used as a reference bythese graduates in obtaining job relevant to their expertise. It is expected that later researchers focus on softskill variables or other possible mediating relationships between the SNP and the graduates' profession. Also, the further researchers need to extent the object of the study.
\end{abstract}

Keywords: National Education Standards, Accounting Education Unit Output, Employment Opportunities Graduates.

\section{PENDAHULUAN}

$\mathrm{P}$ endidikan adalah suatu proses belajar mengajar yang dilakukan dengan sengaja, sadar dan berencana yang membiasakan para warga masyarakat sendini mungkin untuk menggali, mengenal, memahami, menyadari, menguasai, menghayati serta mengamalkan nilai-nilai yang disepakati bersama, dikehendaki serta berguna bagi kehidupan dan perkembangan pribadi masyarakat, bangsa dan negara.

Pendidikan diperlukan untuk meraih kedudukan dan kinerja optimal pada setiap pekerjaan. Pendidikan adalah sebuah sistem formal yang mengajarkan tentang pengetahuan, nilai-nilai dan berbagai keterampilan. Pendidikan diperlukan untuk mendapatkan pekerjaan yang sesuai dengan keahliannya.

Pendidikan kejuruan sebagai salah satu bagian dari sistem Pendidikan Nasional memainkan peran yang sangat strategis bagi terwujudnya angkatan tenaga kerja nasional yang terampil. Intinya lulusan SMK diharapkan menghasilkan sumber daya yang berkemampuan keahlian khusus yang nantinya diharapkan menjadi tenaga siap kerja yang berkemampuan dibidangnya, namun pada kenyataannya Surabaya Metropolis (2010) memaparkan Kementerian Pendidikan Nasional memperkirakan tahun 2010 lulusan SMK yang terserap dalam dunia kerja hanya sebesar 50\%, terdapat 900 ribu pertahun yang belum terserap di dunia pekerjaan dan baru 100 siswa yang memilih melanjutkan ke Perguruan Tinggi sehingga dapat diketahui sisanya yang lebih banyak memilih menganggur. Lulusan yang dimaksud termasuk juga pada lulusan bidang akuntansi yang seharusnya dapat mengisi di bidang ekonomi dan keuangan.

Pemerintah mengeluarkan Peraturan Pemerintah Nomor 19 Tahun 2005 tentang *) Staf Keuangan Unesa 
Standar Nasional Pendidikan (SNP) yang kemudian dibentuk pula Badan Standar Nasional Pendidikan (BSNP) sebagai badan yang menentukan 8 (delapan) standar dan kriteria pencapaian penyelenggaraan pendidikan. Secara umum adanya perbaikan kualitas pelaksanaan program pemerintah ini menjadi suatu angin segar kemajuan pendidikan di Indonesia namun kualitas pendidikan belum juga membaik. Perkembangan pendidikan bukan hanya dapat dilihat dari tingkat kelulusan saja tetapi juga tingkat serapat anak didik dalam dunia kerja.

Standar Nasional Pendidikan merupakan kriteria minimal tentang system pendidikan di seluruh wilayah hukum Negara Kesatuan Republik Indonesia (Pasal 1 PP No. 19 Tahun 2007) untuk meningkatkan mutu sumber daya manusia dan pengukuran kualitas pendidikan. Standar tersebut bukan merupakan ukuran yang statis yang tidak berubah, tetapi semakin lama semakin ditingkatkan. Selain itu standar pendidikan juga berfungsi sebagai pemetaan pendidikan yang bermutu.

Standar Nasional Pendidikan yang terkonsep dan pakem diharapkan akan mampu menghasil output siswa yang lebih baik. Sehingga sekolah akan saling bersaing memperbaiki kualitas hasil belajar siswa. Komponen dalam sekolah terdiri dari Input, proses dan output. Pada pembahasan penelitian ini, peneliti menitik beratkan pada hubungan input dan output sekolah. Keluaran Satuan Pendidikan pada konteks penelitian ini adalah hasil akhir belajar siswa yaitu Ujian Nasional. Lauren Kaluge (2000:1) dalam kuliah on line Unesa, mengartikan output adalah hasil langsung dan segera dari pendidikan. Pernyataan tersebut dikuatnkan oleh NEA (2000:1) kuliah on line Unesa yang menyebutkan output dapat diukur dengan menggunakan istilah volume (banyaknya). Keluaran satuan pendidikan didefinisikan sebagai suatu hasil yang diharapkan dari pembelajaran yang telah ditetapkan dalam rumusan perilaku tertentu sebagai akibat dari proses belajarnya. Ditinjau dari sudut bahasa, penilaian diartikan sebagai proses menentukan nilai suatu objek. Untuk dapat menentukan suatu nilai atau harga suatu objek diperlukan adanya ukuran atau kriteria. Selanjutnya Sudjana $(2005 ; 25)$ menyatakan dengan demikian penilaian adalah proses memberikan atau menentukan nilai kepada objek tertentu berdasarkan suatu kriteria tertentu. Atas dasar tersebut maka dalam kegiatan proses belajar mengajar itu selalu ada objek/program, ada kriteria, dan ada interpretasi (judgment). Interpretasi dan judgement merupakan tema penilaian yang mengimplikasikan adanya suatu perbandingan antara kriteria dengan kenyataan dalam konteks situasi tertentu. Atas dasar tersebut maka dalam kegiatan penilaian selalu ada objek/program, kriteria, dan interpretasi/judgement.

Berikutnya Sudjana (2005:22) juga mengatakan bahwa penilaian hasil belajar adalah proses pemberian nilai terhadap hasil-hasil belajar yang dicapai siswa dengan kriteria tertentu. Hal ini mengisyaratkan bahwa objek yang dinilainya adalah hasil belajar siswa. Hasil belajar siswa pada hakikatnya merupakan perubahan tingkah laku setelah melalui proses belajar mengajar. Tingkah laku sebagai hasil belajar dalam pengertian luas mencakup bidang kognitif, afektif dan psikomotorik. Penilaian dan pengukuran hasil belajar dilakukan dengan menggunakan tes hasil belajar, terutama hasil belajar kognitif berkenaan dengan penguasaan bahan pengajaran sesuai dengan tujuan pendidikan dan pengajaran. Walaupun demikian, tes dapat dapat digunakan untuk mengukur atau menilai hasil belajar di bidang afektif dan psikomotorik.

Rusyan (2000) berpendapat bahwa hasil belajar merupakan hasil yang dicapai oleh seorang siswa setelah ia melakukan kegiatan belajar mengajar tertentu atau setelah ia menerima pengajaran dari seorang guru pada suatu saat. 
Dari pendapat tersebut Keluaran Satuan Pendidikan dapat dimaknai sebagai hasil belajar akhir sebagai proses menentukan nilai suatu objek dimana dalam kegiatan penilaiannya selalu ada objek/program, kriteria, dan interpretasi/judgement.

Harapannya dengan SNP mampu menghasilkan anak didik dengan hasil belajar yang memuaskan, yang nantinya ilmu dan pengetahuan tersebut dapat diaplikasikan dalam dunia kerja. Sumarsono $(2003 ; 41)$ menyatakan secara umum penyediaan (penawaran) tenaga kerja suatu negara atau daerah dipengaruhi oleh berbagai faktor seperti jumlah penduduk, tenaga kerja, pendidikan, perkembangan ekonomi dan lain sebagainya (Sumarsono,2003: 41). Semakin sempitnya daya serap sektor modern terhadap perluasan kesempatan kerja telah menyebabkan sektor tradisional menjadi tempat penampungan angkatan kerja. Hal ini terjadi karena langkanya tenaga yang cukup terdidik karena ekonomi industri membutuhkan tenaga kerja yang terdidik. Buchori (1995:32) menyebutkan mutu angkatan kerja Indonesia dilihat dari keperluan proses industrialisasi sangat tidak memadai. Pasar tenaga kerja, yaitu seluruh aktivitas dari pelaku-pelaku yang mempertemukan pencari kerja dan lowongan kerja. Pelaku-pelaku ini terdiri dari: 1) pengusaha yang membutuhkan tenaga kerja, 2) pencari kerja, dan 3) perantara atau pihak ketiga yang memberikan kemudahan bagi pengusaha dan pencari kerja untuk saling berhubungan.

Dalam permintaan tenaga kerja biasanya perusahaan selalu memperhatikan dari berbagai aspek, salah satunya adalah bagaimana mengisi lowongan yang ada dengan orang yang sesuai (Sumarsono, 2003:108). Jadi dalam hal ini harus ada kesesuaian antara lowongan pekerjaan dengan tingkat pendidikan dan keterampilan dari calon tenaga kerja tersebut.

Penelitian ini meneliti secara keseluruhan komponen dalam Standar Nasional yang diterapkan oleh Sekolah Menengah Kejuruan (SMK) dengan kelompok keahlian akuntansi yang selama ini belum pernah dilakukan penelitian dengan mengambil secara keseluruhan Standar Pendidikan Nasional tersebut. Kelebihan penelitian ini selain meneliti secara keseluruhan komponen SNP sebagai variabel independent juga mencoba menguji hasil belajar siswa sebagai variabel intervening dalam penelitian.

Berdasarkan fenomena tersebut peneliti tertarik untuk membuat suatu penelitian untuk menjawab pengaruh Standar Nasional Pendidikan terhadap Kesempatan Kerja Lulusan siswa bidang keahlian akuntansi SMK di Kota Surabaya, Standar Nasional Pendidikan terhadap Keluaran Satuan Pendidikan siswa bidang keahlian akuntansi SMK di Kota Surabaya dan Keluaran Satuan Pendidikan terhadap Kesempatan Kerja Lulusan siswa bidang keahlian akuntansi SMK di Kota Surabaya. Penelitian ini juga menguji keluaran satuan pendidikan sebagai variabel intervening dalam memediasi Standar Nasional Pendidikan terhadap Kesempatan Kerja lulusan.apakah Keluaran satuan pendidikan mampu memediasi SNP terhadap Kesempatan Kerja Lulusan.

\section{METODE PENELITIAN}

Rancangan penelitian menggunakan pendekatan Kuantitatif dengan tujuan untuk mengetahui signifikansi dari pengaruh variabel : Standar Nasional Pendidikan yang diterapkan oleh SMK Negeri dan Swasta kelompok keahlian akuntansi terhadap kesempatan kerja anak didik tingkat SMK di Kota Surabaya melalui Keluaran Satuan Pendidikan.

Populasi dari penelitian ini adalah Sekolah Menengah Kejuruan baik Negeri maupun Swasta di Kota Surabaya yang memiliki jurusan keahlian akuntansi dan keuangan yaitu 
sebanyak 32 SMK di Kota Surabaya. Penelitian yang dilakukan peneliti merupakan penelitian populasi. Data yang digunakan dalam penelitian ini terbagi menjadi dua yaitu data primer dan data sekunder. Adapun data primer dalam penelitian ini adalah data mengenai prosentase lulusan yang terserap dalam dunia kerja yang diambil melalui wawancara kepada pihak sekolah. Data sekunder pada penelitian ini adalah data nilai ujian nasional yang didapatkan dari arsip Diknas kota Surabaya dan data Penilaian SNP yang didapatkan dari arsip BSN/SM Prov. Jawa Timur. Teknik analisis data yang digunakan dalam penelitian ini menggunakan Parsial Least Square (PLS) dengan konstruksi diagram jalur sebagai berikut :

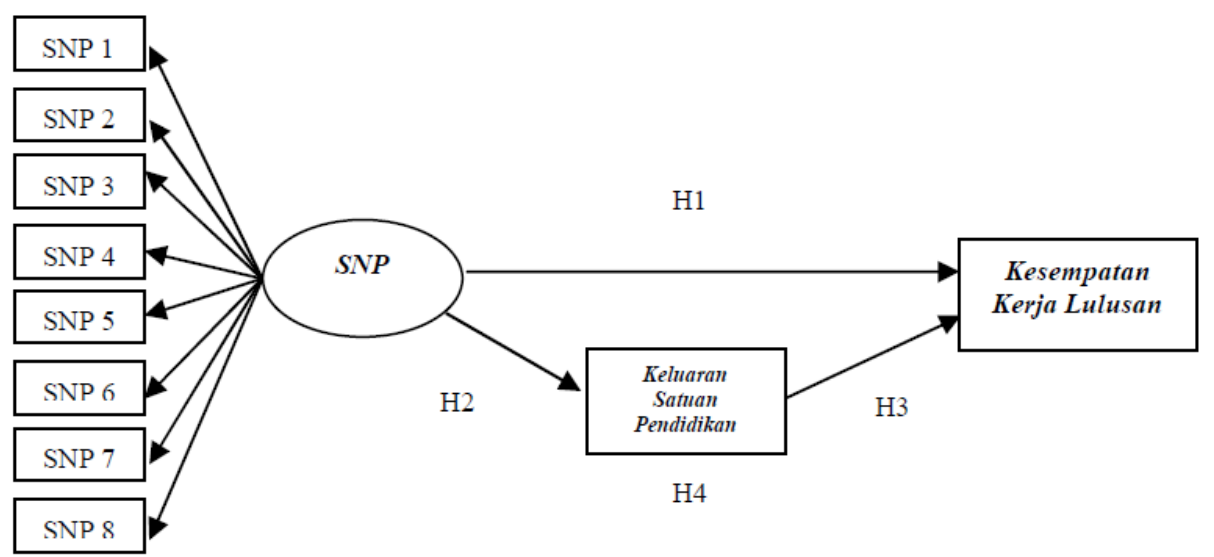

\section{Gambar 1. Model hipotesis SNP terhadap Kesempatan kerja melalui Keluaran Satuan Pendidikan SMK di Kota Surabaya dan model pengukurannya}

Model diatas merupakan model modifikasi dari model second order menjadi first Order.

\section{HASIL PENELITIAN DAN PEMBAHASAN}

\section{Hasil Penelitian}

Pada penelitian ini untuk menguji hipotesis yang digunakan metode Partial Least Square (PLS). PLS tidak mengasumsikan adanya distribusi tertentu untuk estimasi parameter, maka teknik parametrik untuk menguji signifikansi parameter tidak diperlukan (Chin, 1998). Model evaluasi PLS berdasarkan pengukuran prediksi dan mempunyai sifat non parametrik. Oleh karena dalam penelitian ini indikatronya refleksif, maka analisis dengan PLS ada 2 tahap pengujian, yaitu (1) analisis outer model atau measurement model melalui convergent dan discriminant validity serta composite reliability dan (3) pengujian inner model atau model struktural.

\section{Uji Asumsi Linieritas}

Penggunaan PLS seperti halnya model multivariat linier lainnya, menggunakan asumsi hubungan linier antara konstruk eksogen dengan konstruk endogen. Hasil analisis menunjukkan bahwa harga F1 tuna cocok sebesar 0,726 dengan signifikansi 0,740 (diatas 0,05) dan F2 tuna cocok sebesar 0,527 dengan signifikasi 0,893 (diatas 0,05). Berarti model regresi ini dikatakan linear. 
Pengujian Outer Model (Measurement Model)

Outer model atau measurement model atau outer relation adalah penilaian terhadap validitas dan reliabilitas konstruk (variable) penelitian. Ada tiga kriteria untuk menilai outer model: convergent validity, discriminant validity dan composite reliability.

\section{Uji Convergent Validity}

Garson (2000) menyatakan bahwa Convergent validity digunakan untuk menguji apakah indikator-indikator yang digunakan penelitian ini telah mengukur konstruk atau variabel secara akurat. Berdasarkan hasil perhitungan table diatas (kolom original sample estimate) dapat diketahui score item/indicator diatas loading 0,50 sampai 0,60 sehingga indicator individu diatas dapat dikatakan reliable. score item/indicator diatas loading 0,50 menandakan bahwa score item/indicator signifikan dan tidak perlu adanya pembuangan indicator.

\section{Uji Discriminant Validity}

Discriminant validity digunakan untuk menguji apakah indikator-indikator suatu konstruk tidak berkorelasi tinggi dengan indikator dari konstruk lain atau paling tidak indikator-indikator tersebut berkorelasi lebih rendah dengan indikator-indikator konstruk yang lain. Selain memenuhi kriteria validitas konvergen, juga harus memenuhi criteria discriminant validity, yaitu untuk membuktikan bahwa alat ukur tersebut tidak mengukur konstruk lainnya. Discriminant validity pada analisis PLS dilakukan dengan (1) membandingkan loading dengan cross-loading, (2) average variance extracted (AVE), dan (3) membandingkan akar kuadrat AVE dengan korelasi antar variable laten.

Hasil tabel cross loading diketahui bahwa nilai loading indikator pada variabel latennya ternyata lebih tinggi dibanding dengan cross loading indikator variabel laten lainnya. Hal ini mengindikasikian bahwa variabel laten telah memprediksi indikatornya sendiri lebih baik dari pada memprediksi indikator variabel laten yang lain, sehingga dapat diinterpretasi bahwa telah memenuhi kriteria discriminant validity.

Dari Tabel nilai AVE $>0,50$ untuk setiap variabel latent dalam model penelitian. Hal ini mengindikasikan kemampuan variabel laten penelitian ini dalam menjelaskan atau mewakili nilai variabel asli (indikator) telah memenuhi kriteria yang ditetapkan. Selanjutnya, kriteria uji discriminant validity yang lain adalah perbandingan dengan korelasi antar variabel laten. Penjelasan perhitungan, seperti pada Tabel 4.9 dan 4.10 dapat diuraikan sebagai berikut:

Akar AVE (COLOM AVE) untuk variabel KELUARAN SATPEN, KESEMPATAN KERJA, SNP secara berturut - turut adalah 1,$0000000 ; 1,000000 ; 0,634776$.

Variabel Keluaran Satpen, nilai akar AVE $(1,000000)$ lebih tinggi daripada korelasi dengan Kesempatan Kerja (0.132600) dan SNP (0,321319). Hasil ini mengindikasikan indikator-indikator Keluaran Satpen Kesempatan Kerja memiliki convergent validity yang baik dalam mengukur konstruk latennya.

Variabel Kesempatan Kerja, nilai akar AVE $(1,000000)$ lebih tinggi daripada korelasi dengan Kesempatan Kerja (0.132600), dan SNP (0.499569). Hasil ini mengindikasikan indikator-indikator konstruk Kesempatan Kerja memiliki convergent validity yang baik dalam mengukur konstruk latennya.

Variabel SNP, nilai akar AVE $(0,634776)$ lebih tinggi daripada korelasi dengan Keluaran Satpen (0,321319), dan Kesempatan Kerja (0,499569). Hasil ini mengindikasikan 
indikator-indikator konstruk SNP memiliki convergent validity yang baik dalam mengukur konstruk latennya.

Berdasarkan dari kriteria uji validitas secara keseluruhan dapat disimpulkan bahwa semua uji validitas baik convergent validity dan discriminant validity telah memenuhi kriteria dan validitasnya baik.

Uji reliabilitas

Alat ukur selain validitas juga harus memenuhi syarat reliabilitas. Uji reliabilitas berguna untuk menunjukkan sejauh mana suatu alat ukur dapat memberikan hasil yang relatif sama apabila dilakukan pengukuran kembali pada subyek yang sama. Pada penelitan ini, uji reliabilitas menggunakan composite reliability.

Berdasarkan tabel composite reability tingkat reliabilitas pengukuran variabel adalah baik, karena nilainya dari masing - masing score diatas 0,70 .

Pengujian Model Struktural atau Inner Model

Pengujian koefisien jalur pada inner model berarti juga menguji hipotesis yang diajukan pada penelitian ini karena hipotesis yang dirumuskan tercermin pada jalur-jalur yang ada pada model.

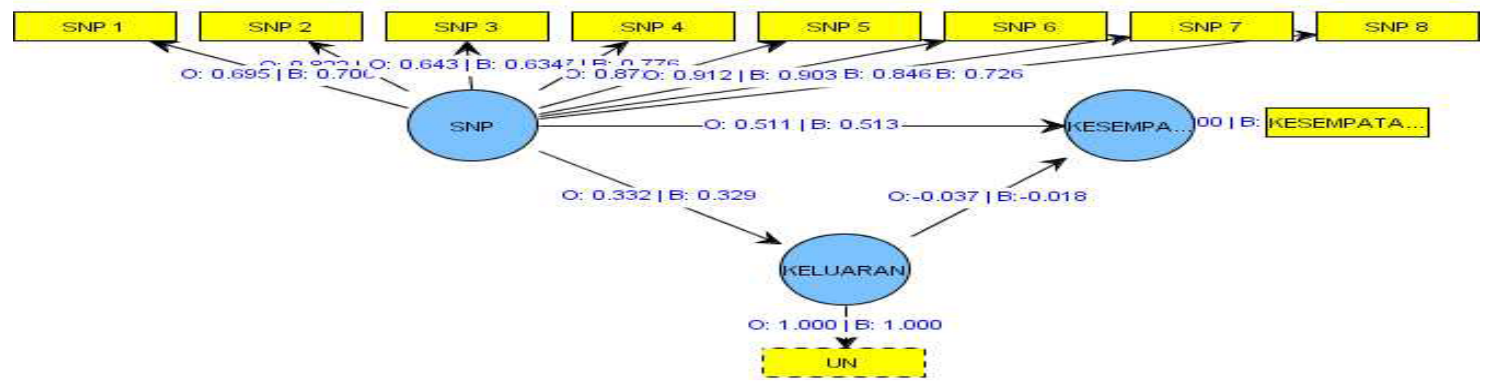

Sumber: Output SmartPLS diolah

\section{Gambar 2. Hasil Inner Model (Original Sample Estimate)}

Uji goodness of fit

Dari output PLS diperoleh nilai koefisien determinasi untuk masing-masing variabel terikat seperti disajikan pada tabel berikut.

Tabel 1.

Hasil R-square

\begin{tabular}{|c|c|}
\hline Variable terikat & R Square \\
\hline Keluaran Satpen & 0,103246 \\
\hline Kesempatan Kerja & 0,250438 \\
\hline
\end{tabular}

Sumber: Output SmartPLS

Selanjutnya berdasarkan nilai koefisien determinasi masing-masing variabel terikat pada tabel 4.12., keluaran Satuan Pendidikan sebesar 0,103246; Kesempatan Kerja Lulusan sebesar 0,250438. Untuk variabel Keluaran Satpen memiliki nilai R-square sebesar 0,103246 yang berarti $10,32 \%$ variance SNP mampu dijelaskan oleh variabel Keluaran Satpen sedangkan sisanya dijelaskan oleh variabel lain di luar model penelitian. Variabel 
Kesempatan Kerja memiliki nilai R-square sebesar 0,250438 yang berarti 25,04\% variance SNP dan Keluaran Satpen mampu dijelaskan oleh variabel Kesempatan Kerja Lulusan sedangkan sisanya dijelaskan oleh variabel lain di luar model penelitian.

\section{Uji Hipotesis}

Ada 4 hipotesis yang diajukan dalam penelitian ini. Hipotesis 1 sampai hipotesis 3 menguji pengaruh langsung, sedangkan hipotesis 4 menguji pengaruh tidak langsung melalui variabel mediator keluaran satuan pendidikan. Koefisien jalur atau hipotesis penelitian terbukti atau tidaknya digunakan cut-off value nilai tstatistik $=1,96$. Dengan demikian, jika tstatistik pada jalur yang diuji $\geq 1,96$, maka hipotesis penelitian terbukti. Hasil pengujian koefisien jalur disajikan pada tabel 2 berikut.

\section{Tabel 2}

Results for inner weights

\begin{tabular}{|l|c|c|c|c|}
\hline \multicolumn{1}{|c|}{ Jalur } & $\begin{array}{c}\text { original sample } \\
\text { estimate }\end{array}$ & $\begin{array}{c}\text { mean of } \\
\text { subsamples }\end{array}$ & $\begin{array}{c}\text { Standard } \\
\text { deviation }\end{array}$ & $\begin{array}{c}\text { T- } \\
\text { Statistic }\end{array}$ \\
\hline SNP > KESEMPATAN KERJA & 0.511 & 0.519 & 0.079 & 6.473 \\
\hline $\begin{array}{l}\text { KELUARAN > KESEMPATAN } \\
\text { KERJA }\end{array}$ & -0.037 & -0.081 & 0.097 & 0.383 \\
\hline SNP > KELUARAN & 0.332 & 0.354 & 0.107 & 3.109 \\
\hline
\end{tabular}

Sumber: Output SmartPLS

Berdasarkan hasil uji hipotesis disimpulkan bahwa hipotesis 1 dan hipotesis 2 terbukti, karena nilai t-statistik yaitu 6,473 dan 3.109 adalah lebih besar 1,96. Ini berarti sumberdaya internal terbukti berpengaruh positif terhadap Kesempatan Kerja Lulusan dan Keluaran Satuan Pendidikan. Pada hipotesis ke 3 ternyata tidak terbukti, karena nilai t-statistik yaitu 0.383 lebih kecil 1,96. Ini berarti Keluaran Satuan Pendidikan terbukti berpengaruh negatif terhadap Kesempatan Kerja Lulusan. Berdasarkan hasil pengujian tersebut dapat disimpulkan bahwa Keluaran Satuan Pendidikan secara langsung tidak berpengaruh terhadap Kesempatan Kerja Lulusan.

Hasil pengujian hipotesis 1 sampai hipotesis 3 tersebut menjadi input dalam pengujian hipotesis 4, yaitu bahwa". Semakin baik Standar Nasional Pendidikan dengan melalui hasil keluaran satuan pendidikan, maka semakin meningkat Kesempatan Kerja lulusan". Pengujian hipotesis tersebut, dilakukan dengan uji mediasi (mediating test). Substansi uji mediasi pada penelitian ini adalah menguji peran strategi bersaing sebagai intervening variable dalam menjembatani pengaruh Standar Nasional Pendidikan terhadap Kesempatan Kerja Lulusan.

Menurut Baron dan Kenny (1986), ada 3 kemungkinan hasil uji mediasi, lebih lanjut, menurut Baron dan Kenny (1986), mediasi penuh terjadi jika memenuhi kriteria.

Koefisien jalur dari variabel bebas ke intervening variable signifikan. Kriteria ini terpenuhi karena konstruk Standar Nasional Pendidikan secara langsung berpengaruh signifikan terhadap Keluaran Satuan Pendidikan.

Koefisien jalur dari intervening variable ke variabel terikat signifikan. Kriteria ini tidak terpenuhi karena konstruk Keluaran Satuan Pendidikan secara langsung tidak berpengaruh signifikan terhadap Kesempatan Kerja Lulusan.

Korelasi sederhana (zero-order correlations) variabel bebas dengan variabel terikat 
signifikan. Kriteria ini terpenuhi karena Standar Nasional Pendidikan, berkorelasi signifikan dengan Kesempatan Kerja Lulusan, yaitu sebesar 0,321319 (Tabel 4.13).

Koefisien jalur dari variabel bebas ke variabel terikat, yang dikontrol oleh intervening variable tidak signifikan. Kriteria ini tidak terpenuhi, karena Standar Nasional Pendidikan secara langsung berpengaruh terhadap Kesempatan Kerja Lulusan SMK di Kota Surabaya, ketika dikontrol intervening variable yaitu variabel keluaran satuan pendidikan.

Berdasarkan penjabaran kriteria uji mediasi tersebut, dapat disimpulkan bahwa hipotesis 4, yaitu "Semakin baik Standar Nasional Pendidikan melalui Keluaran Satuan Pendidikan, maka semakin tinggi Kesempatan Kerja Lulusan." adalah tidak terbukti, karena keempat kriteria uji mediasi tidak terpenuhi secara lengkap. Artinya, posisi keluaran satuan pendidikan sebagai intervening variable, tidak terbukti memediasi pengaruh Standar Nasional Pendidikan terhadap Keluaran Satuan Pendidikan di Kota Surabaya.

\section{Pembahasan}

1. Pengaruh Standar Nasional Pendidikan terhadap Kesempatan Kerja Lulusan siswa SMK di Kota Surabaya

Hasil pengujian hipotesis menunjukkan adanya pengaruh yang signifikan Standar Nasional Pendidikan terhadap kesempatan kerja lulusan siswa SMK di kota Surabaya. Standar Nasional Pendidikan dibuat untuk menyamakan mutu dan kualitas sekolah untuk mengurangi kesenjangan antara sekolah yang satu dengan sekolah yang lain. Pada pelaksanaannya, pelaksanaan Standar Nasional Pendidikan ini diperuntukkan bukan hanya untuk sekolah negeri tapi juga sekolah swasta. Hal tersebut memungkinkan tidak akan adanya kesenjangan kualitas antara sekolah negeri dan swasta, sekolah pinggiran dan tengah kota.

Hasil penelitian ini mengindikasikan pentingnya suatu standar yang menjadi acuan pelaksanaan kegiatan pendidikan pada tataran makro dan mikro seperti yang tertuang dalam UU Sistem Pendidikan Nasional No.20 Tahun 2003 agar penyelenggaraan pendidikan dapat sesuai dengan yang diamanatkan Pancasila dan UUD 1945 yakni pendidikan yang baik dan berkualitas.

Penelitian ini memperkuat hasil penelitian Harahap (2009:196), Ping, Sun et al. (2008:11), Roger Bonner, (2010:15), dan Middle States Commission on Higher Education Second (2007:2-8) yang menghasilkan kesimpulan bahwa Standar Nasional Pendidikan berpengaruh secara langsung terhadap Kesempatan Kerja lulusan meskipun menggunakan sebagian dalam komponen SNP.

Berdasarkan hasil cross loading dapat diketahui bahwa dari ke 8 standar nasional pendidikan melalui loading antar dimensi dan variabel latentnya, tampak bahwa standar pengelolaan paling dominan dalam hubungannya dengan menghasilkan kesempatan kerja lulusan. Suatu organisasi yang baik adalah organisasi yang memiliki manajemen dan pengelolaan yang tepat mulai dari perencanaan, pelaksanaan sampai dengan evaluasi program didalamnya.

Peraturan Menteri Pendidikan Nasional (2007: No. 19) menjabarkan pengelolaan sekolah menjadi tanggung jawab kepala sekolah yang meliputi: (1) Perencanaan Program. (2) Pelaksanaan Rencana Kerja. (3) Pengawasan dan Evaluasi. (4) Kepemimpinan sekolah, (5) Sistem informasi manajemen.

Pada hubungannya dengan Kesempatan Kerja Lulusan, mulai dari perencanaan sekolah harus memiliki visi dan misi yang tujuannya mengarah pada keluaran siswa khu- 
susnya bagaimana kelanjutan siswa setelah lulus dari Sekolah tersebut, menginak Sekolah Menengah Kejuruan mempunyai tujuan agar siswa siap bekerja dengan bekal ilmu dan ketrampilan yang didapatkan di sekolah.

Pelaksanaan rencana kerja dilakukan dengan berasaskan pada efisiensi dan efektifitas kerja, pengawasan dan evaluasi pelaksanaan program dan hasil pengumpulan data mengenai kesempatan kerja lulusan dilakukan secara berkala dengan solusi yang tepat. Kepemimpinan sekolah dalam suatu struktur organisasi mengoptimalkan seuruh komponen dalam sekolah tersebut misalnya Bimbingan Konseling Bursa Kerja untuk melakukan pendataan dan mampu menjalin hubungan baik dengan relasi penyedia lapangan pekerjaan seperti Bursa Kerja, Instansi siap kerja. Seperti halnya pada penelitian World Bank (1994) yang menghasilkan kesimpulan perencana dan pembuat kebijakan harus melibatkan guru, kepala sekolah, dan pengawas dalam untuk meningkatkan kualitas sekolah dalam meningkatkan efektivitas sekolah.

Sistem Informasi manajemen yang baik khususnya dalam penyedia layanan bagi lulusan SMK tersebut agar tetap terjalin hubungan dan menyediakan informasi lapangan kerja untuk lulusan. Temuan ini mendukung penelitian Zenkov et al. (2007:14) dalam journalnya dengan judul Teacher "Quality" and Social Justice Leadership yang menyimpulkan bahwa kualitas guru saja belum mampu menghasilkan keluaran anak didik yang berkualitas dan berdaya saing di dunia kerja. Dibutuhkan kebijakan dan aturan pemerintah untuk mengatur kurikulum dengan penyesuaian potensi masing-masing daerah. Bentuk evaluasi yang disesuaikan dengan kurikulum tersebut dengan program lisensi Guru berfokus pada konsep keadilan sosial kepemimpinan dan sistem penilaian portofolio. Pada intinya keterkaitan pendidik dan manajemen pengelolaan pendidik tersebut sangatlah penting.

Middle States Commission on Higher Education Second (2007:2-8), dalam bukunya yang berjudul Student Learning Assessment menyatakan Karakteristik Excellence di Pendidikan Tinggi yaitu persyaratan dan Standar Akreditasi, untuk memperbaiki persyaratan dan rekomendasi dalam menetapkan tujuan pembelajaran dan menilai prestasi siswa. Karakteristik exelence tersebut dalap dilihat dari bagaimana perguruan tersebut mengelola manajemen instansi tersebut dengan baik.

2. Pengaruh Standar Nasional Pendidikan terhadap Keluaran Satuan Pendidikan SMK di Kota Surabaya

Hasil pengujian hipotesis kedua mengenai pengaruh standar nasional pendidikan terhadap keluaran satuan pendidikan SMK di Kota Surabaya, dapat disimpulkan bahwa hipotesis kedua dapat diterima dan terdukung dengan penelitian sebelumnya. Hal ini berarti keberhasilan siswa dalam menghasilkan nilai ujian nasional sebagai salah satu prasyarat evaluasi yang harus dilewati siswa sangat tergantung dari kepatuhan sekolah dalam menerapkan Standar Nasional Pendidikan di sekolah tersebut. Baiknya pelaksanaan Standar isi, Standar proses, Standar kompetensi lulusan, ketersediaan pendidik dan tenaga kependidikan yang profesional, fasilitas sarana dan prasarana yang memadai, pengelolaan yang tepat, Standar pembiayaan yang sesuai, dan, Standar penilaian yang tepat dapat memotivasi siswa untuk meningkatkan kualitas dirinya sehingga mampu menghadapi ujian nasional sebagai evaluasi akhir sekolah.

Hasil pengujian hipotesis ini memperkuat penelitian yang dilakukan oleh Evans, Cay et al. (2000:200-201), Ayeni, et al. (2012:37-45), Rwand Ministry of Education (2009:5- 
10) yang menjelaskan mengenai keterkaitan antara beberapa kompnen dalam standar nasional pendidikan yang saling mendukung dan memadai serta dukungan pemerintah untuk menciptakan suasana belajar yang nyaman bagi anak didik sehingga menciptakan keluaran yang diharapkan yaitu mencapai nilai maksimal yang telah ditetapkan.

Apabila dilihat dari cross loading dapat diketahui bahwa dari ke 8 standar nasional pendidikan melalui loading antar dimensi dan variabel latentnya, tampak bahwa standar pembiayaan paling dominan dalam hubungannya dengan menghasilkan keluaran satuan pendidikan. Pembiayaan menjadi komponen penting dalam variabel ini, seperti yang telah diamanatkan dalam Permen 2009 bahwa Standar biaya operasi nonpersonalia untuk sekolah diperlukan untuk membiayai kegiatan operasi nonpersonalia selama 1 (satu) tahun sebagai bagian dari keseluruhan dana pendidikan agar satuan pendidikan dapat melakukan kegiatan pendidikan secara teratur dan berkelanjutan sesuai Standar Nasional Pendidikan (Permen, 2009: no. 69 hal.6). didalamnya memuat standar biaya untuk pembelian kebutuhan siswa dan sekolah sekaligus penunjang kegiatan siswa di sekolah.

Pembiayaan yang baik akan memberikan dukungan pada penyediaan fasilitas sarana dan prasarana yang memadai, dan dapat digunakan sebagai pengembangan bidang keahlian bagi siswa dalam sekolah tersebut. Hal ini didukung pula dalam buku Financial and Fiscal Commission For an Equitable Sharing of National Revenue, (2009: 2-16) yang berjudul Submission on Norms and Standards for School Infrastructure menyimpulkan Departemen Pendidikan akan perlu mengembangkan indikator yang akan membuatnya mudah untuk memahami keadaan fisik infrastruktur memadai mendukung pendidikan berkualitas tinggi.

Pentingnya infrastruktur juga diperkuat dengan penelitian Rwand Ministry of Education (2009:5-10) dan Katrien Cuyvers, et al. (2011:1-7) yang menyatakan Standar fasilitas sarana dan prasarana sekolah sangat dibutuhkan. Sebuah sekolah harus memiliki anakanak, lingkungan bebas hambatan yang mempromosikan akses inklusif dan persamaan hak setiap anak. Sekolah harus memiliki peralatan yang memadai dan tepat yang mendukung tingkat pendidikan. Penyediaan sarana prasarana tersebut didapatkan dari pembiayaan yang tepat dari sekolah tersebut dan dengan demikian akan menciptakan suasana belajar yang nyaman bagi siswa untuk menghasilkan prestasi belajar yang sesuai standar. Ternyata infrastruktur sekolah penting peranannya dalam menghasilkan kesejahteraan anak didiknya dalam menimba ilmu.

\section{Pengaruh Keluaran Satuan Pendidikan terhadap Kesempatan Kerja Lulusan siswa SMK di Kota Surabaya}

Hasil pengujian hipotesis ketiga yang mempresentasikan pengaruh Keluaran satuan pendidikan terhadap kesempatan kerja lulusan diperoleh kesimpulan bahwa hipotesis ketiga tidak dapat diterima. Hal ini berarti Keluaran satuan pendidikan dalam hal ini nilai prestasi belajar siswa tidak dapat dijadikan acuan dalam proses pencarian kerja siswa.

Pengaruh yang tidak signifikan antara keluaran satuan pendidikan terhadap kesempatan kerja lulusan ini menyangkal hasil penelitian Zenkov, et al (2007:14), Agus Djumadi (2011), yang memaparkan pentingnya evaluasi akhir berupa Ujian Nasional digunakan sebagai bentuk evaluasi terakhir yang digunakan untuk mengetahui tingkat ketuntasan akhir siswa yang digunakan dalam proses pencarian kerja, nilai tersebut menjadi salah satu bahan pertimbangan manajemen menerima seorang tenaga kerja.

Perusahaan dewasa ini lebih terbuka dan lebih rasional dalam proses rekruitmen pega- 
wainya. Berdasarkan hasil wawancara yang dilakukan kepada masing-masing sekolah di bagian bursa kerja sekolah menyatakan bahwa nilai dan prestasi akademik siswa Sekolah menengak kejuruan belum tentu memberikan jaminan bagi mereka untuk mendapatkan pekerjaan. Perusahaan lebih percaya pada proses seleksi yang dilakukan perusahaan tersebut kepada calon pelamar pekerjaan. Hal ini mengindikasikan pentingnya softskill melebihi prestasi akademik yang dimiliki siswa dalam dunia kerja, mengingat siswa adalah lulusan sekolah Menengah kejuruan yang memang dipersiapkan untuk mengisi kebutuhan akan sumber daya manusia yang terampil dan profesional.

4. Pengaruh Standar Nasional Pendidikan terhadap Kesempatan Kerja lulusan melalui Keluaran Satuan Pendidikan

Hipotesis keempat yaitu mengenai pengaruh positif dan signifikan Standar Nasional Pendidikan terhadap kesempatan kerja lulusan melalui keluaran satuan pendidikan diperoleh kesimpulan bahwa hipotesis dapat tidak diterima. Hal ini berarti baiknya pelaksanaan Standar Nasional Pendidikan akan menghasilkan keluaran satuan pendidikan yang baik pula, namun prestasi akademik tersebut belum dapat digunakan sebagai acuan lulusan tersebut dalam mendapatkan pekerjaan.

Hasil penelitian ini konsisten dengan penelitian Evans, Cay et al. (2000:200-201) bahwa kualitas guru dalam pendidikan nasional belum cukup menghasilkan output anak didik yang berkualitas, perlu adanya dukungan fasilitas sekolah yang memadai, metode pengajaran yang sesuai, kurikulum yang mumpuni dan kebijakan pemerintah dalam dunia pendidikan. Seperti halnya di Indonesia melalui penelitian Harahap (2009:196) memperkuatnya, melalui penelitiannya, mengenai hubungan langsng SNP terhadap kesempatan kerja menjelaskan selain pendidik dna tenaga kependidikan perlu kesinambungan antara komponen sarana dan prasarana, pembiayaan dalam menghasilkan kesempatan kerja lulusan yang diharapkan.

Namun hasil penelitian ini menyangkal penelitian Rasija (2011:9) menyatakan bahwa kualitas guru dan sarana prasarana sekolah mempengaruhi nilai ujian nasional dan mampu menjembatani siswa dalam mendapatkan dan mampu berprestasi di sekolah tingkat lanjutan. Hal ini dimungkinkan karena pada dasarnya penggunaan seleksi tes yang dilakukan sekolah-sekolah pada penelitian tersebut masih berdasarkan nilai ujian akhir tanpa melakukan tes lanjutan. Disisi lain sekolh lanjutan lebih berorientasi pada akademik dan berbeda ranah dengan dunia kerja yang lebih mengedepankan softskill.

Beberapa sekolah menyebutkan nilai dan prestasi akademis siswa belum cukup untuk menjadikan siswa tersebut dapat diterima dalam suatu perusahaan. Faktor lain yang mendukung adalah kemampuan siswa menghadapi tes seleksi yang dilakukan oleh suatu perusahaan, keterampilan siswa dalam bidang tersebut, dan pengalaman siswa dalam perusahaan tersebut misalnya pernah magang.

\section{KESIMPULAN}

Berdasarkan hasil analisis data dan uji hipotesis penelitian serta pembahasan dan hasil penelitian, disimpulkan Standar Nasional Pendidikan berpengaruh signifikan terhadap kesempatan kerja lulusan siswa bidang keahlian akuntansi SMK di Kota Surabaya. Artinya bahwa Standar Nasional Pendidikan berpengaruh positif terhadap kesempatan kerja lulusan siswa bidang keahlian akuntansi SMK di Kota Surabaya. 
Standar Nasional Pendidikan berpengaruh signifikan terhadap keluaran satuan pendidikan siswa bidang keahlian akuntansi SMK di Kota Surabaya. Maknanya Standar Nasional Pendidikan berpengaruh positif terhadap keluaran satuan pendidikan siswa bidang keahlian akuntansi SMK di Kota Surabaya. Keluaran satuan pendidikan berpengaruh tidak signifikan terhadap kesempatan kerja lulusan siswa bidang keahlian akuntansi SMK di Kota Surabaya. Maknanya Keluaran satuan pendidikan berpengaruh negatif terhadap kesempatan kerja lulusan siswa bidang keahlian akuntansi SMK di Kota Surabaya.

Standar nasional pendidikan tidak signifikan terhadap Kesempatan Kerja lulusan saat dimediasi oleh keluaran satuan pendidikan. Artinya, posisi keluaran satuan pendidikan sebagai intervening variabel, tidak terbukti memediasi pengaruh Standar Nasional Pendidikan terhadap Keluaran Satuan Pendidikan siswa bidang keahlian akuntansi SMK di Kota Surabaya.

\section{DAFTAR RUJUKAN}

A Tabrai, Rusyan. 2000. Kemampuan Dasar Guru Dalam Proses Belajar Mengajar. Bandung : Remaja Rosdakarya.

Bonner, Roger. 2010. Delivering Cost Effective and Sustainable School Infrastructure. pp 1-16, (http://www.dfid.gov.uk/Documents/publications1/del-cost-eff-sust-sch-infra.pdf, diakses 15 September 2012)

Cuyvers, Katrien., Weerd, Gio De., Dupont, Sanne., Mols, Sophie., and Nuytten, Chantal. 2011. Wellbeing at school: does infrastructure matter?. International Journal. Institute for Educational and Information Sciences, Instructional and Educational Science, University of Antwerp. Pp 1-7, (http://www.oecd.org/education/educationeconomyandsociety/ centreforeffectivelearningenvironmentscele/49167628.pdf, diakses 15 September 2012)

Chiya, Shiho. 2003. The Importance of Learning Styles and Learning Strategies in EFL Teaching in Japan, International Journal. Susaki Technical High School Kochi Prefecture. pp 1-28, (http://www.kochinet.ed.jp/koukou/kenkyu/kaigaihaken/chiyafinal.pdf, diakses 15 September 2012)

Djumadi, Agus. 2011. Lulus Ujian Nasional dan Angka Pengangguran. Internet Radar Lampung News Network. http://radarlampung.co.id/read/opini/33532-lulus-ujian-nasional-dan-angka-pengangguran

Evans, Cay. Steward., Pamela M., Mangin, Martha., and Bagley, Candi. 2000. "Theacher Quality: Issue and Research”. Louisiana : One University Press.

Nanang, Fatah. 1998. Studi Tentang Pembiayaan Pendidikan Sekolah Dasar. Bandung : Penerbit PT Remaja Rosda Karya.

Garson, (2002). Structural Equation Modelling (Online) (http//www2 chass.ncsu.edu/garson/pa765/structur.htm, diakses 28 april 2002). 
Ghozali, Imam. 2008. Model Persamaan Struktural Konsep dan Aplikasi denan Program Amos 16.0. Semarang: Balai Penerbit Universitas Diponegoro.

Joshua, Ayeni Adeolu. 2012. Achieving quality and standards in the management of Nigerian secondary schools: Policy goals, current practice, trends, challenges, and opportunities, International Journal of Research Studies in Management 2012 October, Volume 1 Number 2, 37-45, (www.consortiacademia.org/index.php/ijrsm/article/download/46/74, diakses 15 September 2012)

Middle States Commission on Higher Education. 2007. American Student Learning Assessment. Printed in the United States of America.

Sudjana, Nana. 2000. Dasar - dasar Proses Belajar Mengajar. Bandung : Sinar Baru Algesindo. http://www.msche.org/publications/SLA_Book_0808080728085320.pdf, diakses 15 September 2012)

Peraturan Pemerintah 19 Tahun 2005 tentang Standar Nasional Pendidikan.

Ping, Sun., Xiaomu, Zeng., Wang, Du. 2008. Delphi Research on Information Literacy Competency Standards for Higher Education in Beijing, China. Chinese Librarianship: an International Electronic Journal, 29. (URL: http://www.iclc.us/cliej/cl25ZSWD.pdf)

UNICEF. 2009. Child Friendly Schools Infrastructure Standards and Guidelines Primary and Tronc Commun schools. Rwanda Ministry of Education Approved document. Pp 5-10, (https://docs.google.com/viewer? $\mathrm{a}=\mathrm{v} \& \mathrm{q}=$ cache:B1gOoz6CLrYJ:toolkit.ineesite. org/toolkit/INEEcms/uploads/1125/Child_Friendly_Schools_Infrastructure.pdf, diakses 15 September 2012)

Sumarsono, Sony. 2003. Ekonomi Sumber Daya Manusia dan Ketenagakerjaan. Jakarta. Graha Ilmu.

Sudjana, Djudju. 2005. Metode dan Teknik Pembelajaran Partisipatif. Bandung : falah Production.

Syam 2008. "Interaksi antara Partisipasi Anggaran dan Penggunaan Anggaran sebagai Alat Ukur Kinerja dengan Orientasi Manajerial”. Simposium Nasional Akuntansi IX. Makasar.

World Bank. 1994. Educational Quality: Defining what's Important.www.google.com

Zenkov Marquez-., Kristen., Corrigan, Dianne. and Brockett, Cristina. 2007 Teacher Quality and social justice Leadership. Clevenda State University. pp 1-15. 